\title{
Clinical Imaging Features of Thyroid Acropachy
}

\author{
Takafumi Taguchi
}

Key words: Graves' disease, thyroid acropachy, EMO syndrome, osteoarthropathy, clinical imaging, musculoskeletal ultrasonography

\author{
(Intern Med Advance Publication) \\ (DOI: 10.2169/internalmedicine.8188-21)
}

Potential Financial Conflicts of Interest: No competing financial interests exist.

Thyroid acropachy is a rare manifestation of autoimmune thyroid disease presenting clinical symptoms of skin tightness, digital clubbing, small-joint pain, and soft tissue edema $(1,2)$. Generally, thyroid acropachy and dermopathy occur with thyroid ophthalmopathy and are considered markers of severe ophthalmopathy (3). Exophthalmos, myxedema, and hypertrophic osteoarthropathy comprise the triad known as "EMO" syndrome, which is seen in less than $1 \%$ of patients with autoimmune thyroid disease having extrathyroid complications (4). Although the exact etiology of thyroid acropachy is unknown, it is thought to be caused by stimulating auto-antibodies to thyroid-stimulating hormone (TSH) and insulin-like growth factor-1 receptors that are involved in the pathophysiology of Graves' thyrotoxicosis and ophthalmopathy (5). The TSH receptor antibody levels, thyroid-stimulating antibody values, and TSH-blocking antibody values are usually extremely high in patients with EMO syndrome $(6,7)$.

The radiographic evaluation of the hand in patients with thyroid acropachy usually shows prominent irregular, frothy, spiculated, and fluffy periosteal reaction in the middiaphyseal areas of the metacarpals, metatarsals, and phalanges with soft tissue swelling $(6,8)$. The periosteal reaction is usually seen along the radial side of the first, second, and third metacarpals or metatarsals and the ulnar side of the fourth and fifth metacarpals or metatarsals $(6,8,9)$. Furthermore, there is limited involvement of the long bones of the forearms or legs (10). These findings are distinctly different from those of the subperiosteal bone resorption seen in primary parathyroidism, although they are the same subperiosteal reactions (11). It is assumed that these reactions depend on the superiority of bone formation or resorption. One of the presumed mechanisms of thyroid acropachy is increased glycosaminoglycan and fibroblast proliferation, which are activated via autoimmune phenomena $(7,10)$. Be- cause of these faint brushed or fluffy periosteal reaction of the bones, it is not easy to detect or evaluate the manifestations using radiography alone (12).

Kawashiri et al. reported the usefulness of musculoskeletal ultrasonography for the evaluation of osteoarthropathy in the phalanges of both the hands and toes in a patient with EMO syndrome (13). Taroumian et al. also reported that musculoskeletal ultrasound can detect periosteal bone formation along with a radiographic examination of the hands in thyroid acropachy (14), although there are only few such reports currently. Further sensitivity and specificity analyses should be performed for this evaluation. Technetium- $99 \mathrm{~m}$ pyrophosphate bone scintigraphy, another imaging modality, showed the focal accumulation of the radionuclide in the affected areas in thyroid acropachy (15). Magnetic resonance imaging is also useful for detecting soft-tissue changes around the periosteal reaction associated with thyroid dermopathy (8).

These complementary diagnostic modalities, including musculoskeletal ultrasonography, are useful for evaluating the clinical imaging features of thyroid acropachy. Further case studies demonstrating the effective treatment and novel techniques of diagnostic imaging modalities in thyroid acropachy are warranted to control the extrathyroid complications of autoimmune thyroid disease in the future.

The author states that he has no Conflict of Interest (COI).

\section{References}

1. Gimlette TM. Thyroid acropachy. Lancet 1: 22-24, 1960.

2. Perini N, Santos RB, Romaldini JH, Villagelin D. Thyroid Acropachy: A Rare Manifestation of Graves Disease in Joints. AACE Clin Case Rep 5: e369-e371, 2019.

3. Fatourechi V, Bartley GB, Eghbali-Fatourechi GZ, Powell CC, Ahmed DD, Garrity JA. Graves' dermopathy and acropachy are markers of severe Graves' ophthalmopathy. Thyroid 13: 11411144, 2003. 
4. Anderson CK, Miller OF 3rd. Triad of exophthalmos, pretibial myxedema, and acropachy in a patient with Graves' disease. J Am Acad Dermatol 48: 970-972, 2003.

5. Jadidi J, Sigari M, Efendizade A, Grigorian A, Lehto SA, Kolla S. Thyroid acropachy: A rare skeletal manifestation of autoimmune thyroid disease. Radiol Case Rep 14: 917-919, 2019.

6. Taguchi T, Nakajima H, Terada Y. Graves' dermopathy and acropachy. Endocrine 49: 296-297, 2015.

7. Elsayad K, Kriz J, Bauch J, et al. Radiation therapy as part of the therapeutic regimen for extensive multilocular myxedema in a patient with exophthalmos, myxedema and osteoarthropathy syndrome: A case report. Oncol Lett 9: 2404-2408, 2015.

8. Vanhoenacker FM, Pelckmans MC, De Beuckeleer LH, Colpaert CG, De Schepper AM. Thyroid acropachy: correlation of imaging and pathology. Eur Radiol 11: 1058-1062, 2001.

9. Guerrero C, Pittelkow MR. IMAGES IN CLINICAL MEDICINE. Thyroid Ophthalmopathy, Dermopathy, and Acropachy. N Engl J Med 375: 261, 2016.

10. Fatourechi V, Ahmed DD, Schwartz KM. Thyroid acropachy: report of 40 patients treated at a single institution in a 26-year pe- riod. J Clin Endocrinol Metab 87: 5435-5441, 2002.

11. Taguchi $T$, Terada $Y$. Images in clinical medicine. Subperiosteal bone resorption. N Engl J Med 370: e32, 2014.

12. Parker LN, Wu SY, Lai MK, Ramadan MB, Rajan RK, Yusi AM. The early diagnosis of atypical thyroid acropachy. Arch Intern Med 142: 1749-1751, 1982.

13. Kawashiri S, Sumiyoshi R, Kawakami A. Musculoskeletal ultrasound manifestation of osteoarthropathy in EMO syndrome. Intern Med 2021 (in press).

14. Taroumian S, Naylor SM, Ben-Artzi A. Clinical Images: ultrasonographic appearance of thyroid acropachy. Arthritis Rheum 64: 3033, 2012.

15. Seigel RS, Thrall JH, Sisson JC. 99mTc-pyrophosphate scan and radiographic correlation in thyroid acropachy: case report. $\mathrm{J}$ Nucl Med 17: 791-793, 1976.

The Internal Medicine is an Open Access journal distributed under the Creative Commons Attribution-NonCommercial-NoDerivatives 4.0 International License. To view the details of this license, please visit (https://creativecommons.org/licenses/ by-nc-nd/4.0/).

\section{(C) The Japanese Society of Internal Medicine} Intern Med Advance Publication 